\title{
Theoretical Research on Autonomous Regional Ethnic Minority Cadres
}

\author{
Zhang Hongtian ${ }^{1}{\text { Zhao } \operatorname{Ran}^{2}}^{2}$ \\ 1. School of Public Administration,Renmin University of china, (Human Resources Management, \\ Read in Dr.)beijing, P.R.China, 100872. \\ School of Tourism , Inner Mongolia University of Finance and Economics,Hohhot, \\ P.R.China, 010051 \\ 2. School of Economics and Management, Chifeng college,Chifeng, P.R.China,024000 \\ (Email:zhht2008@sina.com, zhaoran131@sohu.com)
}

\begin{abstract}
Ethnic cadres is one of the nation in Social Work administration, the subject is related to national and ethnic areas of global social development issues. The realization multi-national area modernization and speeds up the multi-national area the development, cannot leave the high quality national cadre. Highly qualified national cadres is an important guarantee for building a socialist harmonious society. Therefore, building national cadres in ethnic areas is a matter of theory, is the key to national work. To cultivate and bring up a support adapted to the new situation and new tasks of national cadres in line with requirements of building socialism with Chinese characteristics. At the same time, is also part of realizing socialist modernization.
\end{abstract}

Keywords : Human resources, National cadre, National theory, National regions

\section{Introduction}

National cadre is the subject of the management of work in national regions, the quality of nationality cadres skills for sustainable social and economic development in national regions and minority areas social stability. National regions cadre theory construction is the quality of nationality cadres enhanced skills necessary to guarantee. This paper, through national regions of the theory of cadres, improvement of national regions cadre improve quality skills, for the construction of a socialist harmonious society lay the foundation. So as to promote our country's economic and social harmonious and sustainable development.
Appointment of national cadres in ethnic areas issue has been the focus of theoretical and practical work Department in China and one of the issues. From the available research literature at home and abroad, cadre appointments and appointment of cadres and regional autonomy for nationalities, ethnic relations and national policy, and research associated with the content.

\subsection{Present situation of overseas research}

The late 1980s, the mid-1990s, the tense ethnic relations lead to the disintegration of the Soviet Union, former Yugoslavia and the dissolution of Czechoslovakia in the former socialist countries in Eastern Europe. Separatist movement in Quebec, Canada; Germany, the United States, United Kingdom, and Australia's Australia's racism;Sri Lanka's Tamil independence movement; The national struggle in parts of Africa and the Latin American Indigenous people's self-governing movement. India-Pakistan conflict and the Palestine-Israel conflict. Which Canada and other countries, "multiculturalism" is the rise of the West in recent years the theory of national.

In overseas research: Former Soviet Union and the Eastern Europe socialist countries select to the national cadre's raise with the use already have successfully to be possible to study the place for us, the aspect which because also has the policy to appear which the serious fault to cause the national contradictory intensification, the national disintegration lesson is worth us taking warning; National issues and national policy in the United States, Canada and other countries by the form of legislation to protect the rights of ethnic minorities (ethnic), it is built on the premise of sound economic and social systems. Meanwhile, the United States as a country of 
immigrants, typical of its nation-building is not a long time, some ethnic history is not the disputes, the complex is far less than China. Perspective of study abroad based on the position of liberalism, to maintain the purpose of the Western countries, constitutional democracy and free market economy is very clear, and with a strong Western Center on color, national freedom, equality, justice, understanding is completely in the abstract level of political philosophy reflected the deep-rooted inequalities of all races in real life is the root cause of its private ownership, ethnic conflicts and discrimination are also within the range of its system can not be solved. In this regard, we must keep a clear mind. Conducting theoretical draw

\subsection{National Study of the current situation}

From the domestic point of view, in recent years, research on minority cadre appointments into the most active period, the scope of the study no longer stick to the party's ethnic policy and ethnic, starting from the angle of political science, management science, and history research. Research results from the National the macro level, there are also regional at the micro level, both theoretical and empirical evidence analysis.

Wang Xien ,Analysis of the contemporary Chinese national (national press, 2002), Wu Shimin "National Question Introduction" (Sichuan People's Publishing Agency, 2007 ), Duan Chao of the comprehensive construction of well-off society in national work and (Chinese literature press, 2004), Wei Jing the minority leadership cadres of growth study(minzu University of china ,2007).

\section{Ethnic regional autonomy theory and national cadres}

Ethnic regional autonomy is under the unified leadership of the countries, each inhabited by minority nationalities exercising regional autonomy, the establishment of organs of self, to exercise autonomy, the ethnic minority people are the masters, self-management of the internal affairs of the autonomous areas. Autonomous regional system as a basic national policy to solve domestic ethnic problems, and people congress system, the leadership of the Communist Party of China's multi-party cooperation system and political consultation system is a listed as China's three basic political system. Ethnic regional autonomy is a Marxist nationality theory and ethnic relations is actually a combination of a product is a basic policy for solving ethnic problems in China, one of the basic political system, it guarantees the right of ownership of the minority to ensure that national unification and ethnic unity. The premise of ethnic regional autonomy is the country's centralized and unified, the fundamental purpose of all ethnic groups together for unity and struggle, common prosperity and development; the substance of the regional ethnic autonomy is a unified multi-ethnic socialist country, with some neighborhoods minority people under the unified leadership of the state, in accordance with the Constitution, "regional Ethnic Autonomy" and "Civil Service Law and other laws and regulations of the national autonomous areas to exercise the right of ownership and exercise to manage their own internal affairs of the rights. The provisions of Article 112 of the Constitution: The autonomous organs of the People's Congress and people's governments of autonomous regions, autonomous prefectures and autonomous counties. The core of ethnic regional autonomy is the autonomy of the autonomous organs, the key is the cadres, the exercise of autonomy is achieved through the national cadres. To achieve these legal provisions, to allow the minority to really exercise the power of the masters of the country, to manage the internal affairs of ethnic minorities, must be vigorously training, selection and use of national cadres.

Therefore, the implementation of Ethnic regional autonomy, the need for political and professional quality national cadres to take up the burden of national regional autonomy under the unified leadership of the country, and correctly implement the Party's ethnic policies, and implement the Law on Regional Ethnic Autonomy, the exercise of regional ethnicautonomy, the national development of the region well. Great efforts to cultivate and use of national cadres, in order to better regional ethnic autonomy in policy; Therefore, we use the process of appointment of national cadres is also the practice of regional ethnic autonomy process, the practice of regional ethnic autonomy in the process is also a national cadres growth. Strong education, training, selection and use of national cadres, is the consistent policy of our party, but also to 
implement the key to regional ethnic autonomy. Relevant national laws of the nation of the autonomy of local People's Congress, the Government and its departments, staff are clearly defined.

\section{Minority areas of scientific development theory and national cadres}

At present, China has entered a critical stage of the west to open a large accelerated development and building a moderately prosperous society. The face of new situation and tasks, we should recognize the importance and urgency of the development of ethnic regions. Development is a top priority, is the key to solving all the difficulties and problems of the ethnic areas, inspection and implementation of national regional autonomy for the effectiveness of the standard. Due to natural conditions and historical factors, ethnic minorities and their regional economic, cultural and social development is lagging behind compared to the national average and the developed areas there is still a big gap, is to achieve the priorities and difficulties of building a moderately prosperous society areas of our national problems, one of the manifestations.

Marxism is the most critical factor in the productivity. The core of the scientific concept of development is people-oriented, and its essence is the sustainable human development issues. The quality of national cadres is an important indicator of the quality of a nation. High-quality national contingent of cadres is an inevitable requirement of the minority. It can be said that in a certain sense, the harmony of ethnic relations, of all ethnic groups equal status to obtain and rely heavily on the development of each nation's own. A nation to better develop themselves, is inseparable from understanding and grasp of objective and subjective circumstances. All ethnic groups to be very thorough understanding of the objective world and define their tasks and goals very clearly to understand their own history and current situation, to find their own strengths and advantages, and these strengths and advantages to be maximized, while also see their inadequacies, weaknesses, and its essence, to its dregs.

\section{National cadres theory of Marxism}

Highly qualified national cadre ranks are the objective requirements of the final settlement of our national problems, and the appointment of ethnic minority cadres has consistently adhered to the theory of development of Marxism. After the victory of the October Revolution, the cadres of ethnic minority areas is extremely lacking in the status quo. Lenin proposed that the training, selection and use of ethnic minority cadres has great significance to require the whole party should strengthen the training of national cadres, bold selection and use of local ethnic cadres in ethnic minority areas. Stalin's view that national cadres who know the languages and customs of the region's residents, familiar with the situation in the region and the nation, so that they participate in the organs of the Party and the Soviet regime, is the former oppressed national real manifestation of the masters, can stimulate national regional political enthusiasm of the laboring masses and revolutionary enthusiasm. Also pointed out that the party's fundamental task is one of the local residents proletariat molecules and semi-proletariat molecular training and development of the young Communist Party organizations in the national Republic and minority areas, and to unite the truly international communism, the Communist Party cadres; only when truly worthy of the name of the Communist Party organization in the republics and regions to consolidate the Soviet regime in order to consolidate at these places. "Stalin also proposed to take various measures to the appointment of ethnic minority cadres. Such as "the border areas of the Soviet organs of state power as much as possible by local people familiar with the lifestyle of local residents, customs, habits and language"; "absorb all the outstanding elements of the local people to these organs of state power, local working masses attracted to the national management sector (including military), to ";" widely founder of the types of schools at all levels of local ethnic languages as the medium of instruction in order to train the cadres of the party, state cadres, economic management cadres as well as a variety of technical cadres.

The successive leaders of our party is very concerned about and attention to the use of national cadres. As early as the beginning of the party set up, it attaches great importance to the education and training of national cadres, and actively guide them to exercise their own 
to participate in revolutionary activities. Treatment of ethnic minority cadres to "special points and give preferential treatment to point". After the founding of the PRC, Mao Zedong clearly pointed out that "To solve the national question, completely isolated national reactionaries, not a large number of communist cadres from ethnic minority origin, it is impossible." And for the first time asked the government agencies at all levels of ethnic minority cadres with in accordance with minority population, the number of number of seats allocated, this assertion is still today the appointment of national cadres in important guidelines. In February 1951, Mao Zedong asked to work seriously in the minority nationalities, the implementation of regional autonomy and training of minority cadres. October 1954, the CPC Central Committee pointed out in the party in the minority in the past few years work experience in party and the training of party cadres: "the establishment of ethnic minorities is a fundamental problem in solving national problems, ... The ... the outstanding elements in the national cadres should be boldly promoted at all levels of a variety of leadership positions ". Steadily to achieve the minority areas of democratic reform in 1956, Zhou Enlai pointed out: "In ethnic minority areas, to do things to rely on national cadres ... we have to train national cadres, and gradually make them self-government in ethnic autonomous areas institutions, enterprises, schools, the majority, and served as a major leadership positions in August 1957, Zhou Enlai pointed out in the Qingdao National Working Conference on "Since it is a national autonomous, it is necessary to train national cadres ... in each autonomous local, national officials should do the responsible work in 1981, Deng Xiaoping proposed to establish a selection of the standard of national cadres, pay attention to the training and selection of ethnic minority cadres. Jiang repeatedly stressed that the train ethnic minority cadres is "a matter of the overall situation of the important work". In January 1992, Jiang Zemin pointed out in the first Central Ethnic Work Conference to improve the regional ethnic autonomy system, fully implement the "Law on Regional Ethnic Autonomy," the key is to make great efforts to train ethnic minority cadres to strengthen the contingent of cadres of ethnic minority areas. ... the needs of socialist modernization and reform of the Party committees at all levels with greater force, to further strengthen national cadres, especially the senior cadre and a variety of technology, management talents. Incisively discussed the status and role of national cadres in the regional ethnic autonomy. Hu Jintao in ethnic areas for a long time to fully appreciate the importance of the appointment of national cadres. In June 1993, with Comrade Hu Jintao attended the national training and selection of ethnic minority cadres forum pointed out that "the overall situation related to national culture selection of national cadres, is related to the socialist modernization goals can be achieved the correct solution the overall situation is related to social stability, the overall stability of the state. National cadres is an important bridge and link of the party and government with minority people is an important backbone to do national work force. Entering the new century, $\mathrm{Hu}$ stressed that the training of national cadres, selection and use of "decisive significance" to this work as a major task for the tube fundamental to the long term. He pointed out that "good cultivation, selection and use of national cadres, building a politically steadfast, proficient, adept at leading reform and opening up and socialist modernization, by the masses of all the support of high-quality national contingent of cadres, accelerate economic and social development of ethnic minorities and minority areas, to promote our national unity and progress, safeguard national unity and social stability, is of decisive significance. "shows the importance of building a national contingent of cadres, clearly pointed out that the standard of highly qualified national cadres. Enough to see our country several generations of leaders will train ethnic minority cadres at various times as a top priority to solve the ethnic problem and doing national work, profoundly expounded the importance of the issue of ethnic minority cadres appointment.

\section{Minority areas of human resource development theory}

From an economic point of view, the resources are linked value creation or wealth creation, is referred to in the production process used by various input requirements. On the development and utilization of resources in the world of four kinds: material resources, capital resources, information resources and human 
resources, human resources is the only continuous development, the development of deep-seated and endless development of strategic resources. Modern "human resources" management guru Peter Drucker (Peter F.Drucker) formally proposed in a 1954 management practices and clearly defined. Drucker believes that human resources, enterprise employment is the most productive of them all the resources, the most versatile skills, but also the most abundant resources. Human resources is the most fundamental resource of modern society, is the first element of the economic, cultural and social development, the most crucial part of the overall resources of a region. Human resources is the most important asset base of a country, is also an important resource for the development of the country (World Bank, 1997), high-quality human resources is the core competitiveness of a country or region. The quality of human resources determines the level of other resources development, utilization and management level. With economic globalization, the importance of human resources is also crucial outstanding, especially for relatively backward minority areas. Only the quality of the population increase, in order to improve the ability to attract and digestion of foreign investment, and ultimately achieve sustainable development. Minority areas rich natural resources, the development of the biggest obstacles is the quality of the population is relatively high, relatively conservative ideas. To develop minority areas to speed up the development of minority areas, to accommodate the overall interests of China's modernization drive, it must be human resource development as a source of engineering task.

Development in minority areas of human resources, especially human resources development of minority, far-reaching significance. First, human resource development is relatively backward minority areas of economic and cultural poverty, comprehensively building a moderately prosperous society in a fundamental way. Poverty line according to the new adjustment, the poor people of Inner Mongolia is 2,665,800, poverty incidence of $20.34 \%$, the Inner Mongolia region the incidence of poverty is much higher than the national average. The reason for the poverty of the Inner Mongolia region is complex, and the quality of the labor force is relatively low and is one of the main. Only continue to increase human resource development efforts to improve the overall quality and capacity of minority areas the majority of workers, to help them acquire the scientific and cultural knowledge and strong technical skills, and enhance the confidence and determination to change the status quo. Second, human resource development is to achieve national areas to optimize the objective requirements of the industrial structure and changing modes of production. At present, Inner Mongolia's industrial structure is a single, over-reliance on mineral resources, comprehensive utilization of resources development level is not high pressure environment. In June 2101, the State Council promulgated the "on further promotion of the Inner Mongolia economic and social good and rapid development of a number of opinions", the next step to further optimize the investment structure, speed up economic structural optimization and upgrading, and promote the development pattern, strengthen ecological protection and construction, promoting the development of ecological civilization. Whether the adjustment of industrial structure, or industrial structure optimization and upgrade the establishment of mechanisms, and new agricultural, industrial, service establishment of, and are required to have appropriate human resources for protection. Third, human resource development is the key to national regional resource advantages into economic advantages. In recent years, Inner Mongolia, rely on the rapid development of coal and other resource-based industries, to achieve a decade's economic boom in the last century. But too much resource-dependent development model has also brought a single industrial structure, comprehensive utilization of resources development level is not high pressure environment. Full shift the national resource advantages into economic advantages, we must rely on science and technology and high-quality labor resources. Finally, human resources development is an inherent requirement of the national sustainable development. Sustainable development can be summarized as ecological sustainability and sustained economic, cultural continuity and social continued unity of the four. Four ability to unity, depending on the quality of human beings on the level of awareness of sustainable development, human resources, as well as on 
the mode of production, lifestyle, ability to control. Western minority areas, and only through human resource development to enhance the culture of continuous and effective in improving the productivity play a decisive role factors of production in order to achieve sustainable economic development.

\section{Construction of Harmonious Society Theory}

Building a socialist harmonious society, is a major task of the overall situation of our party from building a moderately prosperous society, and create the new situation in the cause of socialism with Chinese characteristics, which has been proposed to adapt to the objective requirements of China's reform and development entered a critical period, reflects the the fundamental interests and common aspiration of the masses. We want to build a harmonious socialist society, should be a democracy and the rule of law, fairness and justice, honesty and fraternity, vitality, stability and order, social harmony with nature.

Building a harmonious society with China's ethnic relations is closely linked to each other between the two conditions interact and mutually reinforcing. Harmonious ethnic relations is the necessary conditions and an important part of a harmonious society is the proper meaning of a harmonious society; and harmonious society and to provide an institutional guarantee for the harmonious ethnic relations. In the historical process of building a socialist harmonious society can not ignore two basic facts: First, China is a united multi-ethnic socialist country, the minority population of nearly 114 million, reaching the number of a large population of the country. Ethnic relations in such a multi-ethnic country, especially the relationship between the Han and the minorities, the country's long-term stability, has great significance. The second is the area of the national autonomous areas in China accounted for more than $60 \%$ of the total area of national stability in the region is essential for the stability of the entire country. Ethnic harmony, social harmony, stresses reform, development and stability can only be empty talk, the goal of building a harmonious society is difficult to achieve. A harmonious socialist society should be harmony between the harmony between man and nature in harmony between people, national and ethnic harmony between man and society. Only to achieve a harmony between these persons in order to achieve truly perfect harmony. Harmony is the essential characteristics of the socialist ethnic relations, ethnic relations harmony, harmony between the Han and minority, but also including minority and ethnic harmony and national internal harmony. We are talking about people's unity, territorial integrity, national unity, are based on the unity of all ethnic groups. If there is no unity of all ethnic groups, our country will be caught in the turmoil and division, and China will not make itself.

The contingent of cadres is the key factor in minority areas to build a harmonious socialist society, only to improve the overall quality of the contingent of cadres of ethnic areas and the ability to govern in order to actively promote the construction of a harmonious socialist society. Contingent of cadres is related to the minority areas key to the construction of a harmonious socialist society, whether it is from the use of the opportunities, the implementation of policies, from which the majority of ethnic people in the region the mobilization of view, the contingent of cadres, especially the national contingent of cadres The building is undoubtedly the first. National contingent of cadres is the key to the rapid development of minority areas take full advantage of the favorable opportunity of western development. Minority areas in China are widely distributed, but also has different characteristics, build a harmonious socialist society in ethnic areas is difficult to regulate one or several development model. Minority areas with local reality, the creative use of the preferential policies of the country, effectively the various ethnic groups of vast areas of national cadres in the region, the internal affairs of the national rights of autonomy, and fully mobilize the nation's political participation, and promote national political, economic harmonious development of the cultural and social aspects are an open-minded, national contingent of cadres actively work hard.

\section{Conclusion}

Cultivating national cadre is a global event relationship, is speeding up national regions modernization and maintain national unity, the construction of socialist harmonious society's 
important assurance, solve problems and to national key national work, cultivate and bring up a adapt to the new situation, the new duty requirement of national cadre, is whether national regions up to speed up the development of social

\section{References}

[1] Liu rong, the communist party of China nationality cadres policy research, [M], social sciences academic press, 2010: 158 .

(In Chinese)

[2] The theory of Stalin's ethnic problems, [M], the national press, 1990. (In Chinese)

[3] MaoGongNing, the collection of ethnic problems [M], the national press, 2001: 256.

(In Chinese)

[4] Peter drucker, the practice of management [M], mechanical industry press, 2006: 218. 